\title{
Stan zaszczepienia przeciwko Streptococcus pneumoniae wśród pacjentów użytkowników implantu ślimakowego - badanie pilotażowe
}

\section{Use of pneumococcal vaccines among patients with cochlear implants - pilot study}

\section{Anna Piotrowska}

Instytut Fizjologii i Patologii Słuchu, Światowe Centrum Słuchu, Zakład Epidemiologii i Badań Przesiewowych, Warszawa/Kajetany

Adres autora: Anna Piotrowska, Światowe Centrum Słuchu, Zakład Epidemiologii i Badań Przesiewowych, ul. Mokra 17, Kajetany, 05-830 Nadarzyn, e-mail: a.piotrowska@ifps.org.pl

\section{Streszczenie}

Cel: Celem pracy była analiza stanu zaszczepienia przeciwko Streptococcus pneumoniae w grupie użytkowników systemu implantu ślimakowego.

Materiał i metoda: Do przeprowadzenia analiz wykorzystano dane uzyskane z badania kwestionariuszowego przeprowadzonego od stycznia do grudnia 2014 roku wśród 1347 pacjentów, którzy zgłosili się na badania kontrolne do Zakładu Implantów i Percepcji Słuchowej Instytutu Fizjologii i Patologii Słuchu.

Wyniki: Odsetek pacjentów zaszczepionych przeciwko pneumokokom w badanej grupie wyniósł 28,5\%, z czego 97,4\% stanowią dzieci. W grupie dzieci 49,3\% badanych otrzymało przynajmniej jedną dawkę szczepienia. W grupie dorosłych pacjenci zaszczepieni stanowią $1,7 \%$.

Wnioski: Stan zaszczepienia przeciwko Streptococcus pneumoniae wśród użytkowników systemu implantu ślimakowego jest bardzo niski, zarówno w grupie dzieci, jak i osób dorosłych.

Słowa kluczowe: implanty ślimakowe • zapalenie opon mózgowo-rdzeniowych • dwoinka zapalenia płuc • szczepienia

Abstract

Aim: Assessment of vaccination against Streptococcus pneumoniae among patients with cochlear implants.

Material and methods: Data from the questionnaire administered to 1347 patients visiting Implants and Auditory Perception Department of the Institute of Physiology and Pathology of Hearing (IAPD) from January to December 2014 were analyzed.

Results: Percentage of vaccinated patients in the study group was $28.5 \%$; $97.4 \%$ of the group were children. $49.3 \%$ and $1.7 \%$ were vaccinated against Streptococcus pneumoniae in pediatric and adult population respectively.

Conclusions: Percentage of patients with cochlear implants who received vaccination against Streptococcus pneumoniae is very low both in pediatric and adult population.

Key words: cochlear implants $\bullet$ meningitis $\bullet$ Streptococcus pneumoniae $\bullet$ vaccination

\section{Wprowadzenie}

Streptococcus pneumoniae (S. pneumoniae, dwoinka zapalenia płuc, pneumokok) jest powszechnie występującym i jednym z najgroźniejszych bakteryjnych patogenów człowieka odpowiedzialnych za szereg chorób inwazyjnych o wysokiej śmiertelności i wielu trwałych powikłaniach $[1,2]$. S. pneumoniae może wywoływać zarówno zakażenia miejscowe, jak i uogólnione. Do chorób inwazyjnych wywoływanych przez pneumokoki należą m.in. 
zapalenie płuc z bakteriemią, posocznica oraz zapalenie opon mózgowo-rdzeniowych (ZOMR) i/lub mózgu i są one określane mianem inwazyjnej choroby pneumokokowej (IChP). Bakteryjne zapalenie opon mózgowo-rdzeniowych stanowi jedną z najczęstszych przyczyn nabytych ubytków słuchu u dzieci [3].

Ponadto S. pneumoniae odpowiada za infekcje nieinwazyjne, takie jak zapalenia ucha środkowego, zapalenia zatok, zapalenia płuc przebiegające bez bakteriemii, czy też rzadziej zapalenia kości, zapalenia otrzewnej, wsierdzia oraz zakażenia tkanek miękkich [4].

Zakażenie S. pneumoniae występuje we wszystkich grupach wiekowych, ale na zakażenia o poważnym przebiegu, z możliwymi licznymi powikłaniami w sposób szczególny narażone są dzieci poniżej 2 r.ż., osoby dorosłe powyżej 65 r.ż. oraz osoby z grup ryzyka. Wśród czynników ryzyka zakażenia $S$. pneumoniae wymienia się m.in.: niedobory odporności, przewlekłe choroby płuc, choroby nowotworowe, przewlekłe choroby serca i układu krążenia, choroby hematologiczne, przewlekłą niewydolność nerek, stan po usunięciu śledziony, choroby metaboliczne (cukrzyca), zakażenie wirusem HIV [4].

Z przeprowadzonych dotychczas badań wynika również, że pacjenci, którym wszczepiono implant ślimakowy, a w szczególności dzieci, mogą być w grupie zwiększonego ryzyka zachorowania na bakteryjne (pneumokokowe) zapalenie opon mózgowo-rdzeniowych [5,6], dlatego też zaleca się osobom z tej grupy szczepienie przeciw $S$. pneumoniae $[7,8]$. Według raportu FDA do października 2003 roku zaraportowano na świecie łącznie 118 przypadków zachorowań na zapalenie opon mózgowo-rdzeniowych po wszczepieniu implantu ślimakowego. S. pneumoniae odpowiadał za $67 \%$ ZOMR o ustalonej etiologii [9]. Na podstawie tych danych nie można jednak wnioskować bezpośredniego o związku przyczynowo-skutkowym pomiędzy wszczepieniem implantu ślimakowego i zwiększonym ryzykiem zachorowania na zapalenie opon mózgowo-rdzeniowych, gdyż z uwagi na brak danych dotyczących zapadalności na ZOMR w populacji pacjentów niesłyszących nie ma możliwości przeprowadzenia analizy porównawczej dla dwóch grup: pacjenci niesłyszący z wszczepionym implantem ślimakowym $v s$ pacjenci niesłyszący bez wszczepionego implantu ślimakowego.

S. pneumoniae kolonizuje nosogardło, bezobjawowe nosicielstwo jest duże u niemowląt oraz dzieci w wieku przedszkolnym i sięga $60 \%$, u dorosłych nosicielstwo wynosi około 10\% [4]. Głównym źródłem zakażenia jest człowiek chory lub zdrowy nosiciel. Przechorowanie zakażenia daje odporność tylko przeciwko konkretnemu typowi pneumokoka, tak więc możliwe jest ponowne ciężkie zakażenie innym typem serologicznym.

Do chwili obecnej opisano łącznie ponad 90 serotypów pneumokoka, z których 11 jest odpowiedzialnych za ponad $70 \%$ inwazyjnej choroby pneumokokowej (IChP) u dzieci na świecie [10].

Według Światowej Organizacji Zdrowia (WHO) pneumokoki są główną przyczyna zakażeń i zgonów na całym świecie; zakażenia pneumokokowe uznane są przez WHO za chorobę o najwyższym priorytecie zwalczania [11]. W roku 2008 ok. 476000 dzieci poniżej 5 roku życia zmarło z powodu zakażenia S. pneumoniae [12].

Według danych KORUN w Polsce w latach 2008-2013 najwyższą zapadalność na IChP notowano u dzieci poniżej 5 roku życia, w tym zwłaszcza u dzieci poniżej 2 roku życia. Wyższą zapadalność niż przeciętna obserwowano również u osób wieku powyżej 60 roku życia [13-16].

W latach 2011-2013 rejestrowano w Polsce rocznie do 192 zachorowań na zapalenie opon mózgowo-rdzeniowych i/lub mózgu wywołanych przez S. pneumoniae [17-19], z czego ponad 50\% zakażeń dotyczyło osób powyżej 45 roku życia $[18,19]$. Zachorowania u dzieci w wieku od 0 do 4 lat stanowiły w roku 2013 9,5\%, zapadalność dla tej grupy wiekowej była najwyższa i wyniosła ogółem 0,89 na 100 tys. [19].

Szczepienie, poprzez zwiększenie odporności, stanowi skuteczną formę zapobiegania zakażeniom S. pneumoniae. Pierwsza skuteczna 14-walentna szczepionka została zarejestrowana w 1977 roku, a w 1983 r. wprowadzono, aktualną do dziś szczepionkę 23-walentną [20]. Pierwsza skoniugowana szczepionka 7 -walentna została zarejestrowana w roku 2000, w roku 2009 zarejestrowano szczepionkę 10-walentną, a w lutym 2010 roku wprowadzono szczepionkę 13-walentną [21].

Obecnie dostępne są w Polsce: szczepionka polisacharydowa (nazwa handlowa Pneumo 23) oraz szczepionki skoniugowane - 10-walentna (nazwa handlowa Synflorix) i 13-walentna (nazwa handlowa Prevenar 13). Zgodnie z Programem Szczepień Ochronnych w Polsce na rok 2015 szczepienie przeciw S. pneumoniae zaleca się m.in. wszystkim pacjentom, którzy są użytkownikami systemu implantu ślimakowego. Informacje nt. wskazań do szczepień, zarówno obowiązkowych, jak i tych zalecanych, powinny być, zgodnie z ustawą o chorobach zakaźnych z 5 grudnia 2008 roku, udzielane przez każdego lekarza.

\section{Cel}

Celem pracy była analiza stanu zaszczepienia przeciwko $S$. pneumoniae w grupie użytkowników systemu implantu ślimakowego.

\section{Material i metoda}

Dane dotyczące stanu zaszczepienia przeciwko S. pneumoniae uzyskano na drodze wywiadu standaryzowanego z wykorzystaniem kwestionariusza ankiety opracowanego przez autora. Kwestionariusz przygotowano w wersji dla dzieci (pacjenci $<18$ roku życia) oraz dla dorosłych (pacjenci $\geq 18$ roku życia). Aby zapewnić jednorodność wyników badań, określono warunki pomiaru. Wywiad zbierany był przez jednego z dwóch prowadzących (lekarz lub pielęgniarka) w dniu wizyty, w gabinecie lekarskim. W każdym przypadku wywiad przebiegał zgodnie z opracowanym kwestionariuszem. Przed rozpoczęciem wywiadu prowadzący informował respondenta (pacjenta lub rodziców/opiekunów pacjenta) o celu badań oraz zapewniał o ich anonimowości. W kwestionariuszu wyróżniono dwie części: część I - zawierającą pytania dotyczące 


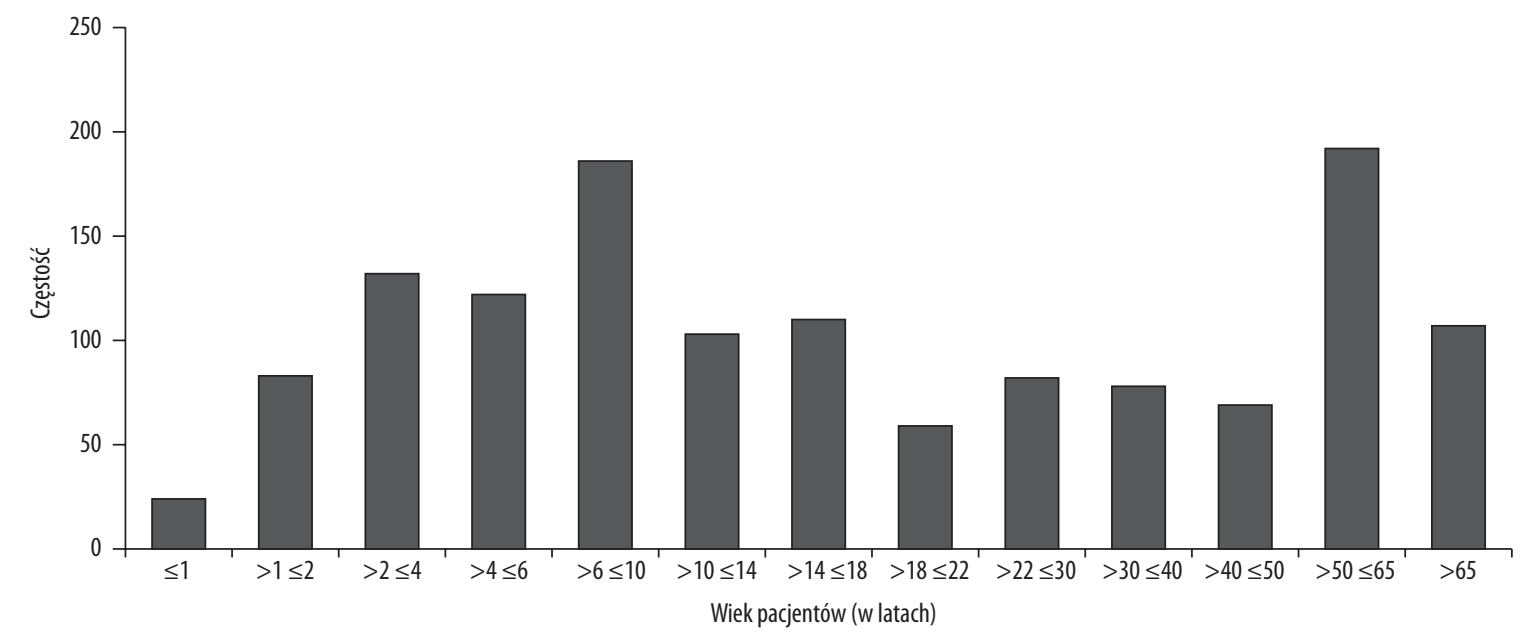

Rycina 1. Histogram wieku w badanej grupie

Figure 1. Age distribution in the study group

zasadniczego problemu badań, część II - zawierającą tzw. pytania metryczkowe, tzn. pytania o cechy demograficzno-społeczne respondenta. Wszystkie pytania części I kwestionariusza były neutralnymi pytaniami o fakty dotyczące badanego problemu i miały charakter pytań zamkniętych. Poprawność danych dotyczących szczepień u dzieci sprawdzano dodatkowo w Książeczce zdrowia.

Do oceny stanu zaszczepienia przeciwko S. pneumoniae w grupie użytkowników systemu implantu ślimakowego wykorzystano dane kwestionariuszowe zebrane podczas wywiadów przeprowadzonych u pacjentów, którzy zgłosili się na kontrolę do Zakładu Implantów i Percepcji Słuchowej (ZIPS) Instytutu Fizjologii i Patologii Słuchu (IFPS) w roku 2014. Program Implantów Ślimakowych Instytutu Fizjologii i Patologii Słuchu należy obecnie do największych na świecie (ponad cztery tysiące pacjentów). Od 1 stycznia do 31 grudnia 2014 roku na wizytę do ZIPS zgłosiło się, przynajmniej jeden raz, łącznie 1877 pacjentów, z czego 1347 (72\%) osób wzięło udział w badaniu. Pozostałe 530 osób odbywało wizytę w dniu, w którym nieobecne były osoby przeprowadzające wywiad.

\section{Wyniki}

Wiek pacjentów w badanej grupie w dniu badania zawierał się w przedziale od 7 miesięcy do 84 lat (średnia wie$\mathrm{ku}-24,5$ roku, mediana - 14 lat), 50\% pacjentów było w wieku od 5 do 44 lat (rycina 1).

Odsetek pacjentów zaszczepionych przeciwko S. pneumoniae w badanej grupie ( $\mathrm{n}=1347)$ wyniósł $28,5 \%$, z czego $97,4 \%$ stanowią dzieci. W grupie dzieci $49,3 \%$ badanych otrzymało przynajmniej jedną dawkę szczepienia. Ponad $80 \%$ zaszczepionych dzieci stanowią dzieci urodzone w roku 2007 i później (dzieci urodzone w tych latach stanowią $58 \%$ całej grupy dzieci). W grupie dorosłych pacjenci zaszczepieni stanowią 1,7\%. W 47 przypadkach respondent nie miał wiedzy o tym, czy było szczepienie przeciwko pneumokokom (4\% kwestionariuszy dla dzieci, 2,5\% kwestionariuszy dla dorosłych). 99\% ankietowanych pacjentów dorosłych do chwili badania nie słyszało o szczepieniu przeciwko pneumokokom.

W badanej grupie 34\% stanowią pacjenci mieszkający na wsi, z czego $28 \%$ było szczepionych przeciwko pneumokokom. Porównywalny odsetek pacjentów zaszczepionych $(28,7 \%)$ stwierdzono w grupie osób zamieszkałych w mieście. W grupie dzieci $40 \%$ zamieszkuje na wsi, z czego $42 \%$ otrzymało szczepienie. Odsetek dzieci zaszczepionych i mieszkających w mieście wynosi 54\% i dzieci te stanowią $66 \%$ wszystkich dzieci szczepionych w badanej grupie.

Analiza danych demograficznych wykazała, że pacjenci w badanej grupie pochodzą ze wszystkich województw Polski. Najwięcej pacjentów, którzy zgłosili się na wizytę kontrolną w ZIPS w roku 2014 oraz najwięcej pacjentów zaszczepionych przeciwko S. pneumoniae (104 osoby, w tym 2 dorosłych), było z województwa mazowieckiego (rycina 2).

Odsetek zaszczepionych dzieci w poszczególnych województwach zawierał się w przedziale od 36\% do 70\%. Największy odsetek zanotowano w województwie zachodniopomorskim, najniższy w kujawsko-pomorskim (rycina 3). W populacji polskiej w latach 2012-2013 najwięcej osób i najwyższy odsetek zaszczepionych $(0,8)$ zgłoszono w województwie mazowieckim $[18,19]$.

Analiza zmiennej demograficznej - „wykształcenie matki” wykazała, że najwięcej dzieci (195) oraz najwyższy odsetek (62\%) dzieci zaszczepionych przeciwko pneumokokom jest w grupie dzieci matek $\mathrm{z}$ wykształceniem wyższym.

Najwyższy odsetek dzieci zaszczepionych (64,6\%) stwierdzono u dzieci matek w wieku 21-30 lat (wiek w momencie szczepienia); natomiast najwięcej dzieci (211) zdecydowały się zaszczepić matki w wieku 31-40 lat.

Występowanie przynajmniej jednego czynnika ryzyka IChP (innego niż wszczepienie implantu ślimakowego) stwierdzono u 347 pacjentów (27,8\%), z czego 45\% stanowiły dzieci. W grupie dzieci przynajmniej jeden 


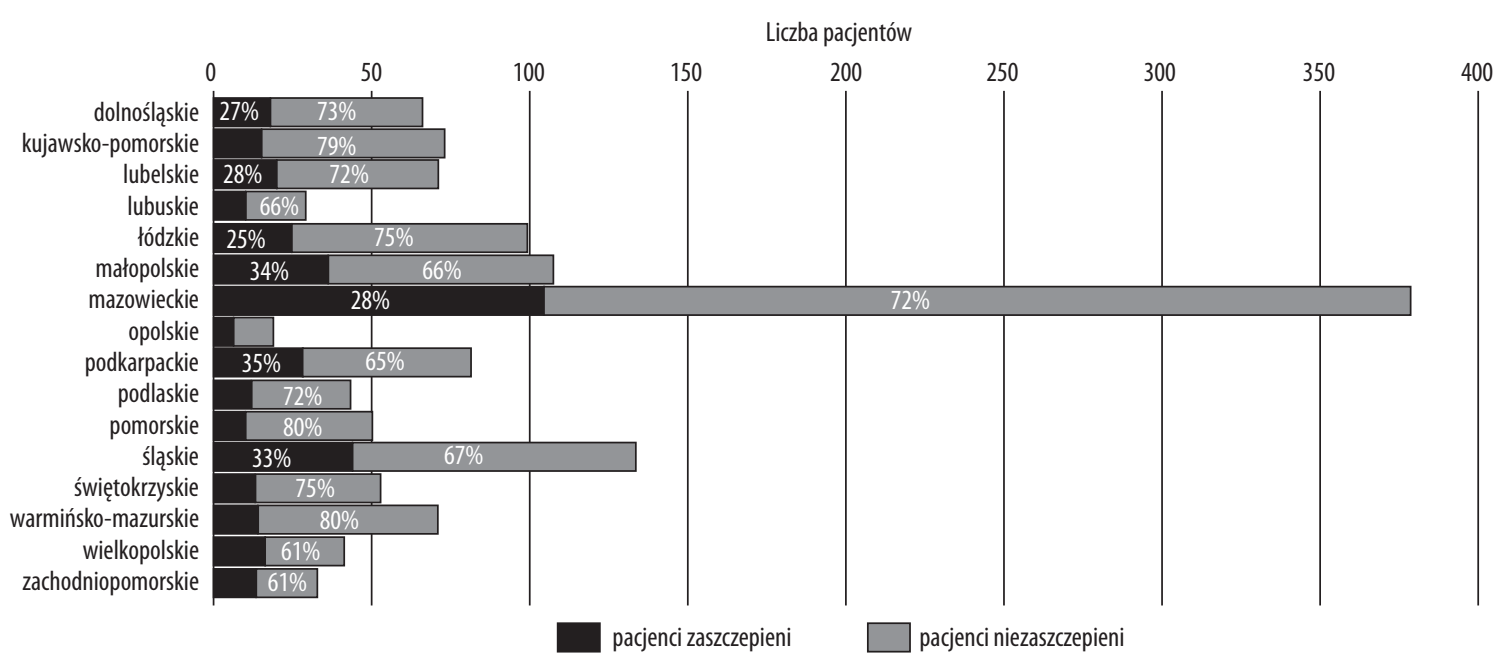

Rycina 2. Liczba pacjentów z poszczególnych województw, którzy zgłosili się na badanie kontrolne do ZIPS w roku 2014, oraz odsetek osób zaszczepionych (czarne) i niezaszczepionych (szare) wg województw

Figure 2. Number of patients from the study group who had a control visit at IAPD in 2014 and the percentage of vaccinated (black) and non-vaccinated (grey) individuals

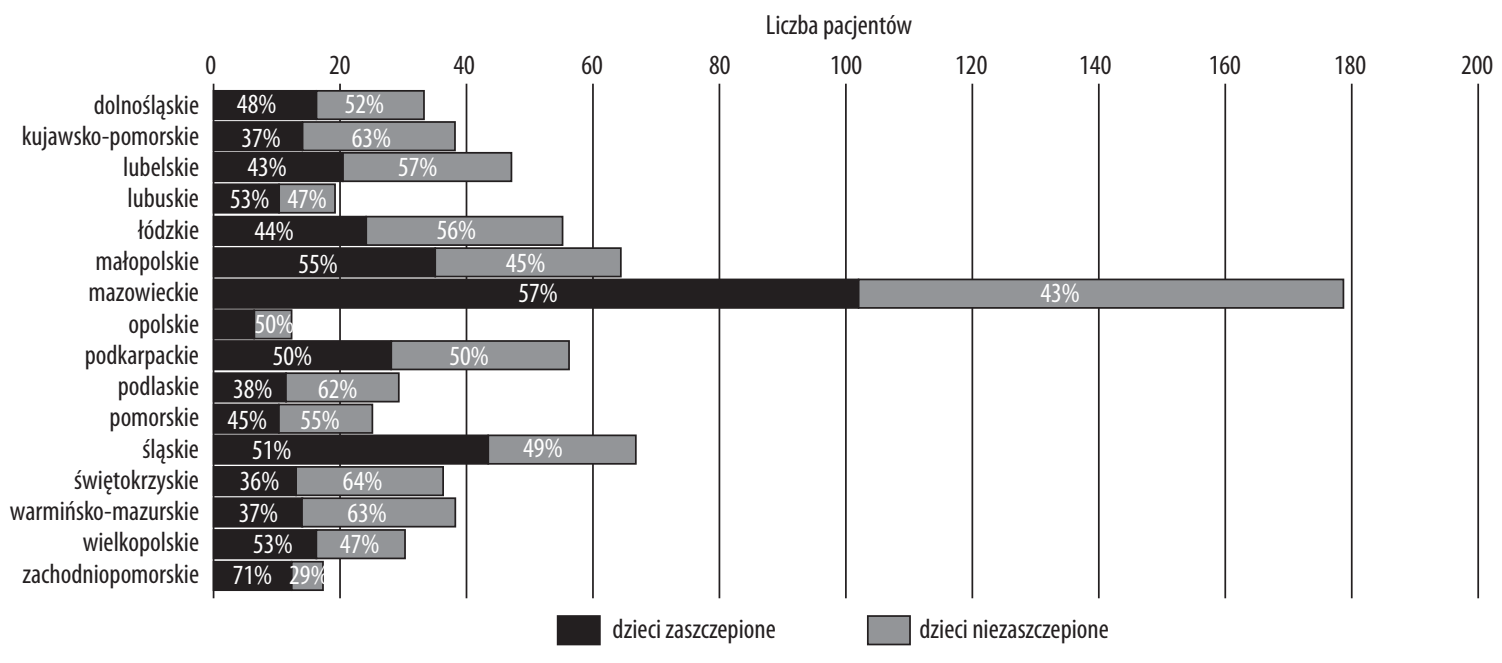

Rycina 3. Liczba dzieci z poszczególnych województw, które zgłosity się na badanie kontrolne do ZIPS w roku 2014, oraz odsetek dzieci zaszczepionych (czarne) i niezaszczepionych (szare) wg województw

Figure 3. Number of children from the study group who had a control visit at IAPD in 2014 and the percentage of vaccinated (black) and non-vaccinated (grey) individuals

czynnik ryzyka IChP (inny niż wszczepienie CI) występował u 20,6\% pacjentów, w grupie dorosłych u 32,3\% osób badanych.

Najczęściej zgłaszanymi czynnikami ryzyka u dzieci były wcześniactwo i niska waga urodzeniowa. Ponad 50\% dzieci urodzonych przedwcześnie i/lub z niską wagą urodzeniową zostało zaszczepionych przeciwko $S$. pneumoniae (rycina 4).

W grupie dzieci zaszczepionych przeciwko pneumokokom $76 \%$ stanowiły dzieci, których rodzice nie zgłosili innych niż wszczepienie implantu ślimakowego czynników ryzyka IChP.
Najczęstszym czynnikiem ryzyka IChP zgłaszanym przez pacjentów dorosłych były przewlekłe choroby serca i układu krążenia (rycina 5).

\section{Dyskusja}

Wysoka zachorowalność i umieralność z powodu zakażeń pneumokokowych, zwłaszcza u dzieci poniżej 2 roku życia, osób w wieku powyżej 65 lat oraz osób z grup ryzyka, mają istotny wpływ na rosnące znaczenie działań profilaktycznych, a szczególnie szczepień ochronnych [1].

American Academy of Pediatrics wprowadziła szczepienie przeciwko Streptococcus pneumoniae do kalendarza 


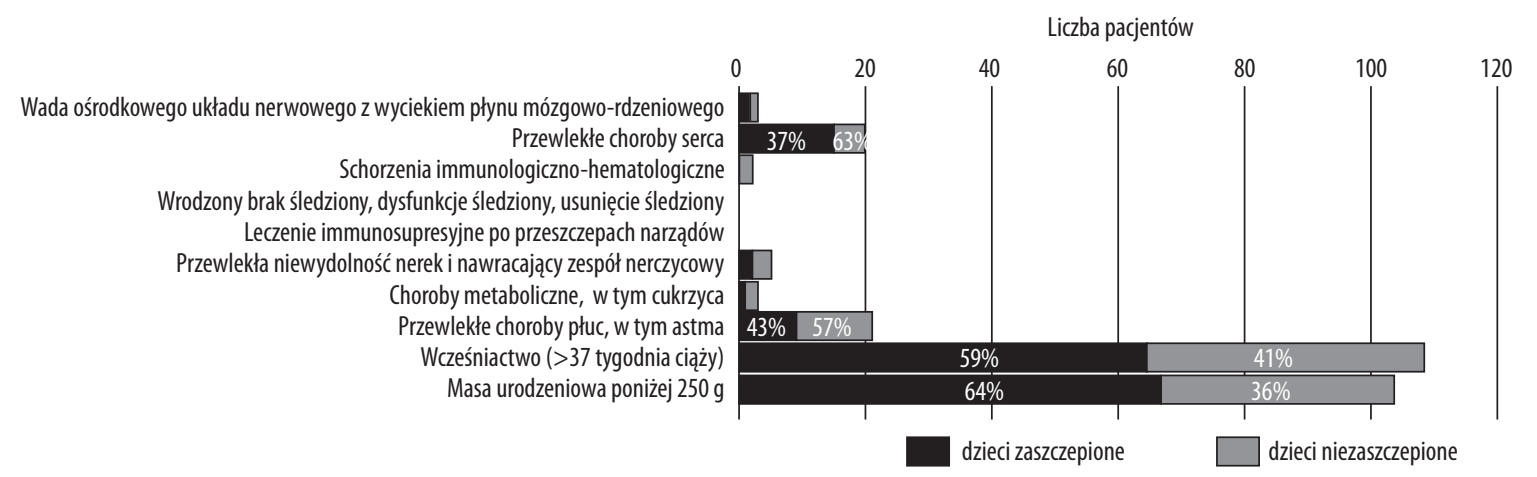

Rycina 4. Liczba dzieci, u których wystąpiły wymienione czynniki ryzyka IChP, oraz odsetek dzieci zaszczepionych (czarne) i niezaszczepionych (szare) wg czynników ryzyka

Figure 4. Number of children with listed risk factors for invasive disease and the percentage of vaccinated (black) and non-vaccinated (grey) individuals according to risk factor

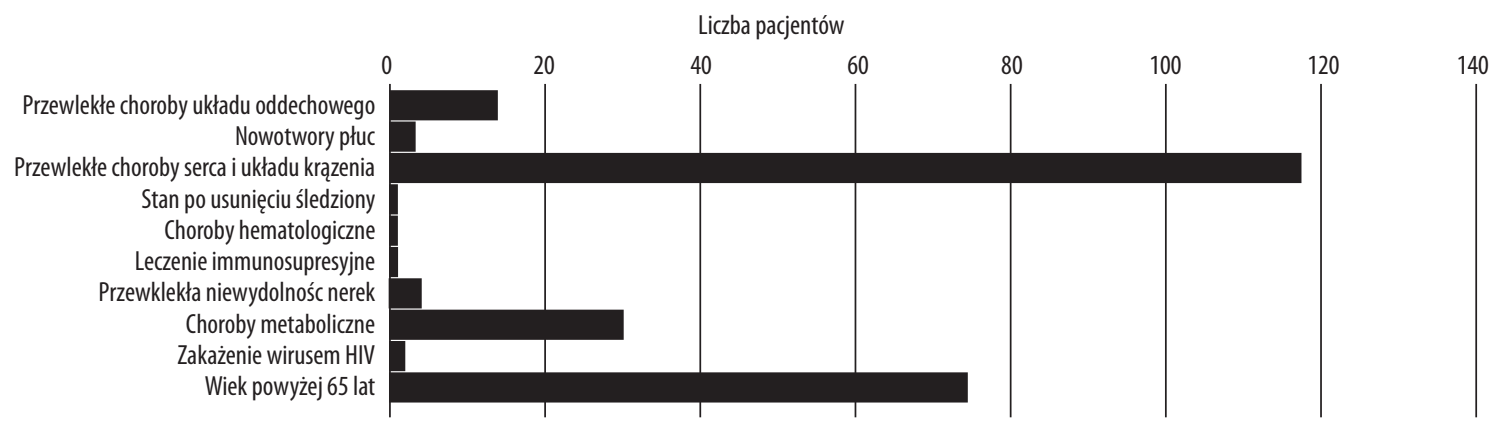

Rycina 5. Liczba pacjentów dorosłych zgłaszających wymienione czynniki ryzyka IChP

Figure 5. Number of adults reporting listed risk factors of invasive disease

szczepień rutynowo zalecanych każdemu zdrowemu niemowlęciu [7]. W lutym 2013 roku amerykański Advisory Committee on Immunization Practices (ACIP) wydał zalecenie rutynowego stosowania skoniugowanej 13-walentnej szczepionki przeciwko pneumokokom [8]. W Polsce od roku 2009 szczepienie to znajduje się na liście szczepień obowiązkowych, tj. bezpłatnych, jedynie dla dzieci od $2 \mathrm{~m}$-ca życia do 5 roku życia z grup ryzyka, tj. narażonych w sposób szczególny na zakażenie, w tym m.in. dzieci przed wszczepieniem lub po wszczepieniu implantu ślimakowego. W pozostałych grupach wiekowych, tj. u dzieci $>5$ roku życia oraz osób dorosłych, szczepienie to jest zalecane.

W latach 2009-2014 operację wszczepienia implantu ślimakowego przeprowadzono u 695 osób z badanej grupy, z czego 45\% (311) stanowiły dzieci, które w chwili operacji nie przekraczały 5 roku życia. 209 dzieci (67\%) z tej grupy otrzymało szczepienie przeciwko pneumokokom.

Pacjenci będący w chwili operacji w wieku, w którym istnieje szczególne narażenie na IChP, tj. dzieci, którym wszczepiono implant ślimakowy przed ukończeniem 2 r.ż., oraz osoby operowane w wieku powyżej 65 r.ż., stanowili odpowiednio $48 \%$ oraz $13 \%$ danej grupy, z czego $67 \%$ dzieci i $3 \%$ pacjentów dorosłych otrzymało szczepienie przeciwko pneumokokom.
U wszystkich pacjentów z badanej grupy występował przynajmniej jeden czynnik ryzyka IChP, tj. wszczepienie implantu ślimakowego. Występowanie dodatkowych, innych niż wszczepienie implantu ślimakowego, czynników ryzyka potwierdziło $30 \%$ badanych. W tej grupie odsetek osób zaszczepionych przeciwko S. pneumoniae wynosi tylko $27 \%$, z czego $98 \%$ stanowią dzieci.

Miejsce zamieszkania pacjenta - wieś lub miasto - nie wpływało istotnie na odsetek osób szczepionych, w obydwu przypadkach wartość ta zawierała się w przedziale 28-29\%. Czynnikiem istotnym, który może mieć wpływ na decyzję o szczepieniu dziecka, jest w niniejszym badaniu wykształcenie matki.

\section{Podsumowanie i wnioski}

Według danych epidemiologicznych w ciągu ostatnich lat odnotowuje się w Polsce wzrost liczby osób szczepionych przeciw S. pneumoniae [18,19]. W roku 2012 ponad 90\% wśród osób szczepionych stanowiły dzieci do 4 r.ż. [19]. Pomimo tego liczba użytkowników systemu implantu ślimakowego, którzy otrzymali szczepienie przeciwko $S$. pneumoniae, jest bardzo niska, zwłaszcza w grupie dzieci starszych i osób dorosłych. 
Wiedza oraz świadomość społeczna na temat szczepień przeciwko pneumokokom oraz celowości ich stosowania jest znikoma, szczególnie w grupie dorosłych użytkowników systemu implantu ślimakowego. Fakt ten oraz konieczność pokrywania kosztów szczepionki ze środków własnych mogą mieć istotny wpływ na stan zaszczepienia przeciwko $S$. pneumoniae w tej grupie pacjentów.
Wskazane jest podjęcie systemowych działań mających na celu zwiększenie świadomości w zakresie wskazań do szczepień przeciwko pneumokokom $\mathrm{w}$ grupie pacjentów przed wszczepieniem lub po wszczepieniu implantu ślimakowego.

\section{Piśmiennictwo:}

1. Hryniewicz W. Szczepionki przeciwko zakażeniom wywołanym przez Streptococcus pneumoniae. W: Magdzik W, Naruszewicz-Lesiuk D, Zieliński A, red. Wakcynologia. Bielsko-Biała: $\alpha$-medica press; 2007, s. 502-8.

2. Opinia Grupy Ekspertów na temat skuteczności szczepień ochronnych przeciwko Streptococus pneumoniae. Parasol Dla Życia, Warszawa; 2014.

3. Fortnum HM. Hearing impairment after bacterial meningitis: a review. Arch Dis Child, 1992; 67(9): 1128-33.

4. Zasada A. Zakażenia paciorkowcowe. W: Baumann-Popczyk A, Sadkowska-Todys M, Zieliński A, red. Choroby zakaźne i pasożytnicze - epidemiologia i profilaktyka. Bielsko-Biała: $\alpha$-medica press; 2014, s. 545-51

5. Biernath KR, Reefhuis J, Whitney CG, Mann EA, Costa P, Eichwald J i wsp. Bacterial meningitis among children with cochlear implants beyond 24 months after implantation. Pediatrics, 2006; 117(2): 284-9.

6. Reefhuis J, Honein MA, Whitney CG, Chamany S, Mann EA, Biernath KR i wsp. Risk of bacterial meningitis in children with cochlear implants. N Engl J Med, 2003; 349: 435-45.

7. Policy Statement: Recommendations for the prevention of Streptococcus pneumoniae infections in infants and children: Use of 13-Valent Pneumococcal Conjugate Vaccine (PCV13) and Pneumococcal Polysaccharide Vaccine (PPSV23); Committee on Infectious Diseases. Pediatrics, 2010; 126(1): 186-90.

8. CDC: Use of 13-valent pneumococcal conjugate vaccine and 23-valent pneumococcal polysaccharide vaccine for adults with immunocompromising conditions: recommendations of the Advisory Committee on Immunization Practices (ACIP). MMWR, 2012; 61: 816-9.

9. U.S. Food and Drug Administration. Public health web notification: risk of bacterial meningitis in children with cochlear implants. Available at: $w w w . f d a . g o v / c d r h /$ safety/cochlear.html. Accessed February 9, 2010.
10. Johnson HL, Deloria-Knoll M, Levine OS, Stoszek SK, Freimanis-Hance L, Reithinger R i wsp. Systematic evaluation of serotypes causing invasive pneumococcal disease among children under five: the pneumococcal global serotype project. PLoS Medicine, 2010; 7(10): e1000348.

11. Pneumococcal vaccines - WHO position paper - 2012. Weekly epidemiological record, 2012; 14(87): 129-44.

12. Estimated Hib and pneumococcal deaths for children under 5 years of age, 2008 (http://www.who.int/immunization_monitoring/burden/Pneumo_hib_estimates/en/index/html, accessed March 2012).

13. Inwazyjna choroba pneumokokowa $\mathrm{w}$ Polsce $\mathrm{w}$ latach 2006-2011 - wybrane dane KOROUN. Warszawa, 05.07.2012.

14. Inwazyjna choroba pneumokokowa $\mathrm{w}$ Polsce $\mathrm{w}$ latach 2008-2012 - wybrane dane KOROUN. Warszawa, 16.11.2013.

15. Inwazyjna choroba pneumokokowa w Polsce w 2013 roku - wybrane dane KOROUN. Warszawa, 31.03.2014.

16. Skoczyńska A, Kuch A, Gołębiewska A, Waśko I, Ronkiewicz R, Markowska M i wsp. Inwazyjna choroba pneumokokowa w Polsce w roku 2010. Pol Merkur Lek, 2011; 31/182: $80-5$.

17. Lipke M, Karasek E. Zapalenia opon mózgowo-rdzeniowych i zapalenia mózgu w Polsce w 2011 roku. Przegl Epidemiol, 2013; 67: 327-30.

18. Paradowska-Stankiewicz I, Piotrowska A. Zapalenia opon mózgowo-rdzeniowych i zapalenia mózgu w Polsce w 2012 roku. Przegl Epidemiol, 2014; 68: 333-6.

19. Paradowska-Stankiewicz I, Piotrowska A. Zapalenia opon mózgowo-rdzeniowych i zapalenia mózgu w Polsce w 2013 roku. Przegl Epidemiol, 2015; w druku.

20. Grzesiowski P, Betlejewska K, Hryniewicz W. Immunoprofilaktyka zakażeń Streptococcus pneumoniae wobec narastającej oporności na leki przeciwbakteryjne. Nowa Medycyna, 1999; 9: 27-31.

21. Korona-Głowniak I, Niedzielski A. Nosicielstwo Streptococcus pneumoniae a rozwój choroby pneumokokowej. Otolaryngologia, 2013; 12(1): 1-7. 